\title{
The ecology of and fishery for Coryphaena spp. in the waters around Australia and New Zealand*
}

\author{
MICHAEL J KINGSFORD ${ }^{1}$ and ANTHONY DEFRIES ${ }^{2}$
}

\begin{abstract}
${ }^{1}$ School of Biological Sciences A08, University of Sydney, NSW 2006, Australia. E-mail: mikek@bio.usyd.edu.au ${ }^{2}$ Scientific Coordinator, AFZ Observer Program, Australian Fisheries Management Authority (AFMA), BOX 7051, Canberra Mail Centre, ACT 7051, Australia. E-mail: Anthony.DeFries@afma.gov.au
\end{abstract}

\begin{abstract}
SUMMARY: Two species of dolphinfish, Coryphaena hippurus and Coryphaena equiselis, are found in Australian waters and off the north-eastern coast of New Zealand. Both species (also called Mahi-mahi, or dorado) are generally found in tropical waters, but only $C$. hippurus is captured in southern waters (to $34^{\circ} \mathrm{S}$ ). Dolphinfish are caught by recreational and commercial fishers, using either trolled or baited lines. Most catch records do not allow the identification of fish to the species level. Dolphinfish are also an incidental catch of foreign and domestic pelagic fisheries (e.g. long-lining for tunas and billfishes) and 10-70 tonnes are taken per year in the Australia-New Zealand region. Although Coryphaena are known to associate with objects (e.g. traps for carangids and navigation buoys) and are a focus for recreational fishers, Fish Attraction Devices (FADs) are not used by commercial fishers off the coast of Australia and New Zealand. FADs are, however, used by fishers in the Pacific Islands. Recreational catches of Coryphaena may exceed the commercial catch in some areas. Good data for New South Wales, Australia, gave estimates of 11.7 and 12.7 tonnes of Coryphaena caught in 1994 and 1995 respectively, which represented 1.1-1.8x the recorded commercial catch. Approximately $~ 12,600$ fish have been tagged since 1973 around Australia and data on returns are only available for 108 fish (0.86\% recovery). Tagged Coryphaena were found to move distances of up to 440 kilometres and at estimated speeds of up to 20 kilometres per day. The time between tag and recapture varied from 0-360 days and fish moved 0-440 kilometres. The majority of fish were caught around the same drifting object near where they were tagged. The collection of Coryphaena larvae in Queensland and New South Wales, along the east coast of Australia, indicates spawning in these waters. Most larvae have been collected in the austral summer and autumn and typically in surface waters well offshore. Dolphinfish have been successfully raised from eggs to fish of marketable size in Western Australia and the species appears to be an excellent candidate for mass production, which is now possible in Australia.
\end{abstract}

Keywords: Coryphaena, distribution, fishery, movements, larvae, aquaculture, Australia, New Zealand.

\section{INTRODUCTION}

Dolphinfishes (Pisces: Coryphaenidae) are panoceanic and are most common in tropical-temperate waters. Both species, Coryphaena hippurus Linneaus 1758 and Coryphaena equiselis Linneaus 1758 , are captured by recreational and com-

\footnotetext{
*Received October 23, 1997. Accepted October 15, 1998.
}

mercial fishermen in waters around Australia and New Zealand. C. hippurus is most commonly caught and has been collected to $38^{\circ} \mathrm{S}$ in Australia (Gomon et al., 1994). It is most common in open water on the east and west coasts of Australia (FAO, 1984), where it is captured by domestic and international fleets. Coryphaena are usually a by-catch of pelagic species fisheries for yellowfin and bluefin tuna (Kailola et al., 1993; Ward 

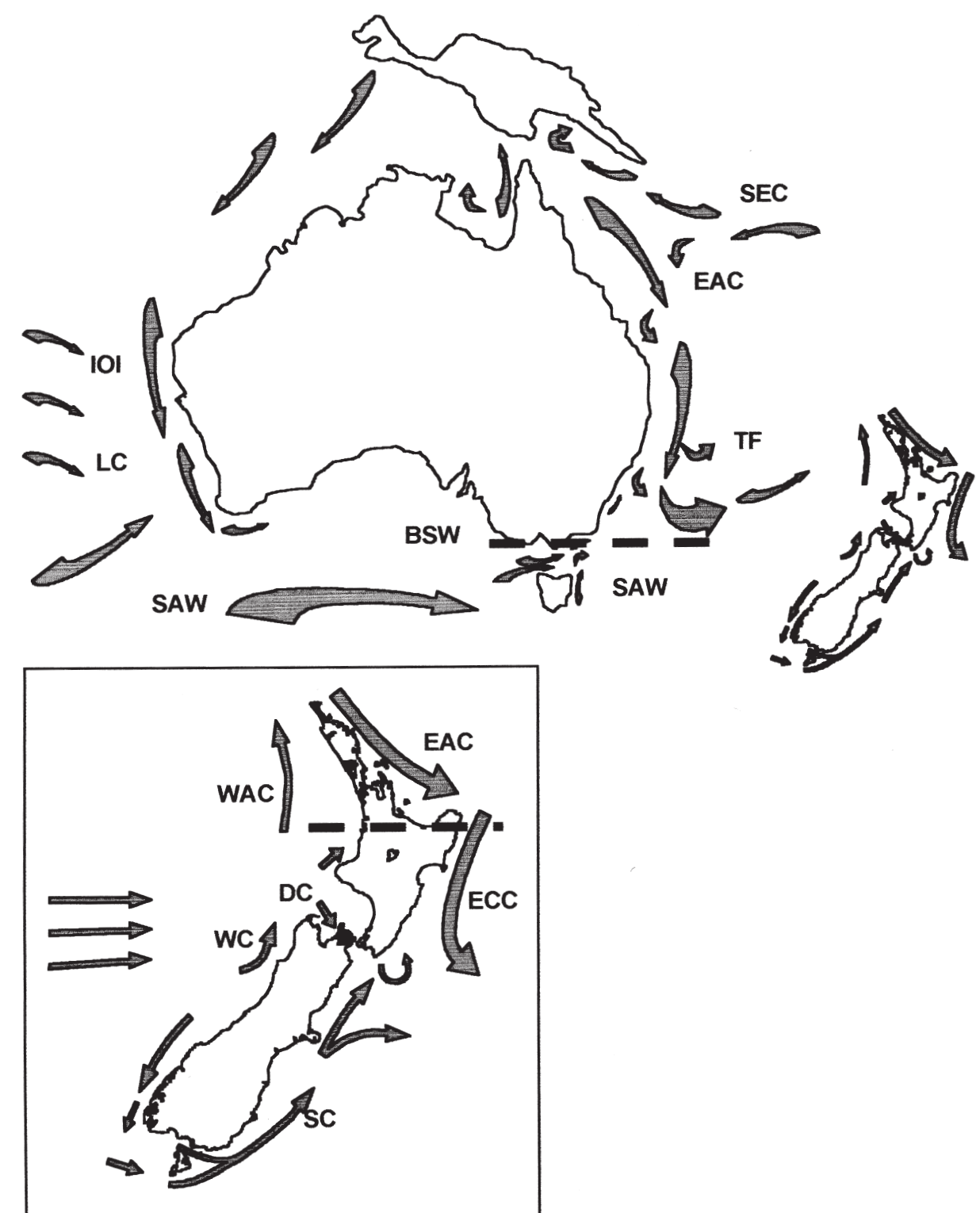

FIG. 1 - Major currents and average direction of flow off the coasts of Australia and New Zealand: Abbreviations: BSW=Bass Strait Waters; DC=Durville Current; EAC=East Australia Current (off Australia, warm); EAC=East Auckland Current (off New Zealand, warm); ECC=East Coast Current (warm); IOI=Indian Ocean Inflow; LC=Leeuwin Current (warm); SAW=Sub-Antarctic Waters; SC=Southland Current; $\mathrm{SEC}=$ South Equatoral Current (warm); TF=Tasman Front (warm); WAC=West Auckland Current; WC=Westland Current. Hatched lines equal the approximate southern limit of Coryphaena hippurus southern Australia $\left(\sim 38^{\circ} \mathrm{S}\right.$, Gomon et al., 1994) and New Zealand $\left(\sim 38^{\circ} \mathrm{S}\right.$, Ayling and Cox, 1982).

1996). Australia and New Zealand are influenced by warm tropical currents (Fig. 1) and catches of most Coryphaena are captured in or close to these currents, as for Japan (Kuwahara et al., 1982) and California (Norton and Crooke, 1994). Long-liners target tuna in warm waters and as a result take Coryphaena as by-catch. For example, yellowfin tuna are often targeted in waters of $\sim 26^{\circ} \mathrm{C}$ (Baron, 1991).

The objective of this paper is to give an overview of the data available on the ecology, larval stages, movements (from tagging), fishery and aquaculture of Coryphaena spp. in waters around Australia and New Zealand. Limited information is available on most of these subject areas because the objectives of most sampling designs, and catch data, did not focus on dolphinfishes and there are certainly no ecological justifications for different stocks ( $c f$ Oxenford, 1986, for the Western Atlantic). Although most data are pooled at the level of genus, anecdotal accounts suggest that the majority of larvae and adults collected were $C$. hippurus. 
TABLE 1. - Catches of Coryphaena by the Japanese longline fishing vessels off Australia. Observation period = months of the year that observers were present on vessels; Number weighed = number of fish weighed from the number of fish observed.

\begin{tabular}{|c|c|c|c|c|c|c|c|c|c|c|}
\hline Year & Coast & $\begin{array}{l}\text { Months of } \\
\text { Fishing }\end{array}$ & $\begin{array}{l}\text { Observation } \\
\text { Period }\end{array}$ & $\begin{array}{c}\text { Observed } \\
\text { Hooks }\end{array}$ & $\begin{array}{l}\text { Fleet } \\
\text { Hooks }\end{array}$ & $\begin{array}{c}\text { Fish } \\
\text { Observed }\end{array}$ & $\begin{array}{l}\text { Number } \\
\text { Weighed }\end{array}$ & $\begin{array}{l}\text { Weight } \\
\text { (kg) }\end{array}$ & $\begin{array}{l}\text { Hooks } \\
\text { per fish }\end{array}$ & $\begin{array}{l}\% \text { hooks } \\
\text { observed }\end{array}$ \\
\hline 92 & East & $1-11$ & $1-9$ & 636,902 & $8,236,129$ & 129 & 117 & 1,322 & 4,937 & 7.7 \\
\hline 93 & East & $1-12$ & $2-10$ & 493,111 & $8,198,713$ & 259 & 243 & 2,454 & 1,903 & 6 \\
\hline 94 & East & $1-9$ & $2-9$ & 345,767 & $8,219,562$ & 230 & 193 & 2,345 & 1,503 & 4.2 \\
\hline 95 & East & $1-10$ & $2-9$ & 283,621 & $7,199,339$ & 41 & 39 & 344 & 6,917 & 3.9 \\
\hline 96 & East & $6-9$ & $6-9$ & 375,439 & $3,537,035$ & 57 & 21 & 147 & 6,586 & 10.6 \\
\hline 92 & West & $1-5$ & $2-3$ & 43,787 & 432,172 & 1 & 1 & 5 & 43,787 & 10.1 \\
\hline 93 & West & $1-12$ & $1-10$ & 200,262 & $1,712,774$ & 19 & 13 & 49 & 10,540 & 11.6 \\
\hline 94 & West & $1-12$ & $1-2$ & 54,332 & $1,439,013$ & 1 & 0 & 0 & 54,332 & 3.8 \\
\hline 95 & West & $1-11$ & $2-2$ & 7,591 & $1,199,602$ & 1 & 0 & 0 & 7,591 & 0.6 \\
\hline 96 & West & $6-10$ & $6-8$ & 61,683 & 873,008 & 10 & 1 & 7 & 6,168 & 7.1 \\
\hline
\end{tabular}

\section{REVIEW}

\section{Fishery in Australia}

Near Australia, the majority of Coryphaena are taken by Japanese long-liners, licensed under a bilateral agreement which is negotiated annually. There is also a substantial recreational fishery in Australia. The Japanese vessels generally target yellowfin or bigeye tuna and to a lesser extent southern bluefin tuna and broadbill swordfish. Dolphinfish are usually considered a low value by-catch. The areas fished that are relevant to Coryphaena are the east coast and west coast of Australia. Japanese long-liners must operate north of $34^{\circ} \mathrm{S}$ and outside of 50 miles from the coast. Area and effort limits apply and these have varied over the years (Ward, 1996). Most of the longline domestic fleet operates from the shelf break (200m contour) at distances ranging from $50-100 \mathrm{~nm}$ from shore.

Observers are placed on a proportion of Japanese long-line vessels each season. The collection of biological data is one of their objectives, but observers are asked to concentrate their efforts on target species and the biological data for by-catch species is often not as thorough as for scombrids and billfish. Data collected on Coryphaena would include: (i) number caught per observation period; (ii) number of hooks observed during each observation period; (iii) Life status on landing (i.e. a 6 point scale from 'dead and damaged' to 'alive and vigorous'); (iv) Whether the fish were retained or discarded; (v) Length from snout to caudal fork; (vi) Sex (rarely recorded and of questionable quality); (vii) whole weight (if possible); (viii) retained weight if processed.

Dolphinfish are normally processed by removal of the caudal and pectoral fins and frozen whole.
The weight of the retained product is within $10 \%$ of the whole weight. Observers also calculate the proportion of hooks hauled that they have observed on each fishing day (normally around $70 \%$ of the total hooks set). This allows observer data to be extrapolated to the entire fleet. Japanese vessels are required to report catches and effort daily. However, dolphinfish are recorded as an 'other species' in vessel records and as such are not distinguished from other retained by-catch species like wahoo (Acanthocybium solandri) opah (Lampris guttatus) and ray's bream, (Brama brama).

Japanese fleets are active in permitted areas for most of the year (Table 1), but effort is often low or zero from the end of the austral spring. The estimated number of hooks used by the fleets ranges from

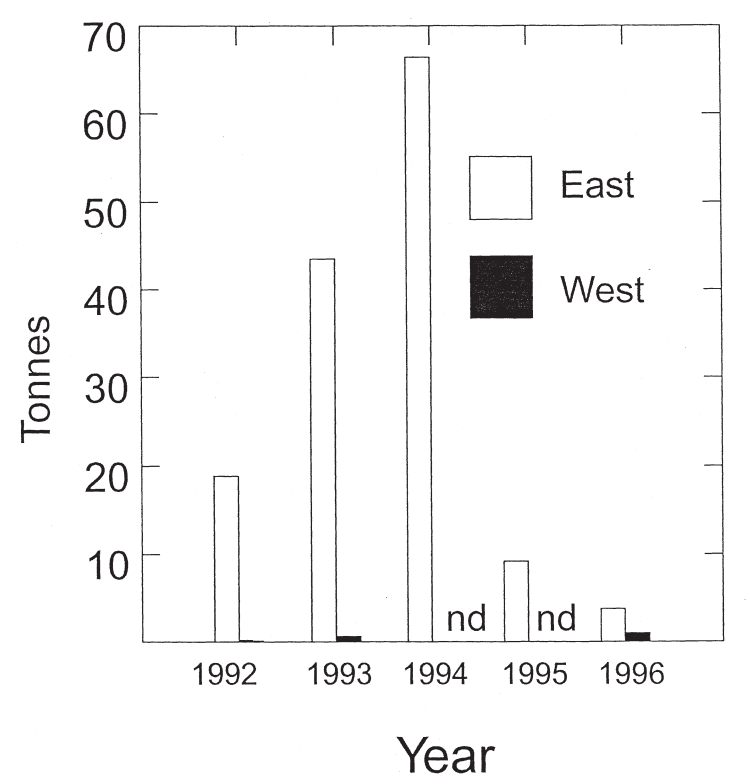

FIG. 2 - Estimated tonnes of Coryphaena taken by international fishing vessels on the west and east coast of Australia. This estimate is based on interpolation to total hooks for the fleet from the number of Coryphaena and hooks observed; nd = no data. 


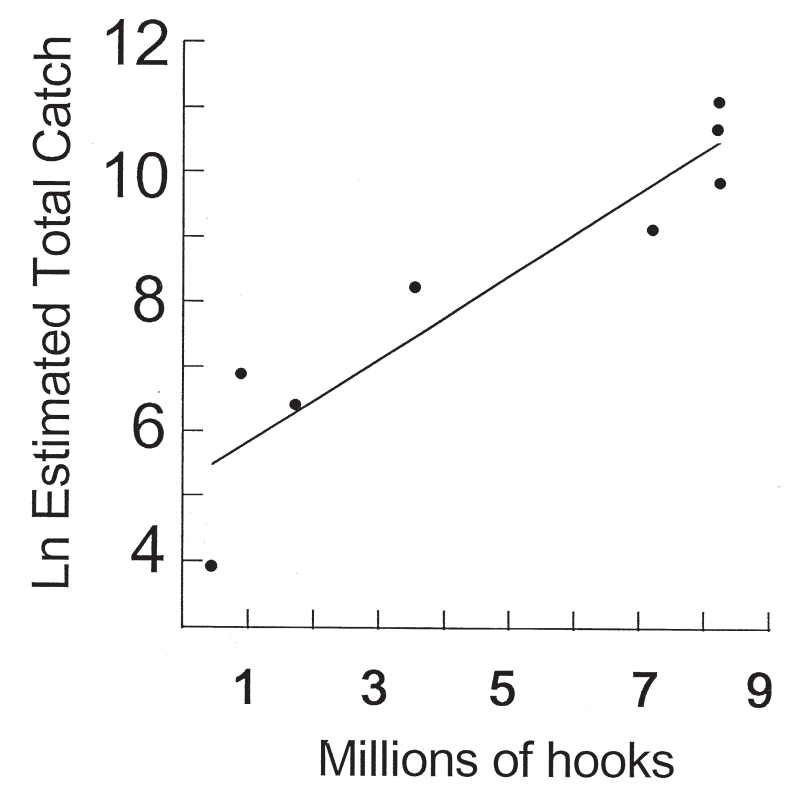

FIG. 3 - The relationship between number of hooks and the natural $\log$ of total catch (tonnes). Correlation: $\mathrm{r}=0.837, \mathrm{df}=6, \mathrm{P}<0.01$.

3.3 to 8.3 million hooks on the east coast and 800,000 to 1.7 million on the west coast. The percentage of hooks observed is generally $5-10 \%$, but coverage is best for the east coast fleets. In two years, coverage of less than 5\% were recorded for the west coast fishery. The majority of Coryphaena taken by international fleets is recorded off the east coast of Australia (Table 1). The number of hooks deployed for each Coryphaena taken was 1,503 to 6,586 on the east coast and 7,591 to 10,540 on the west coast. The estimated total catch of fish ranged from 3.7 to 66 tonnes on the east coast and 0.05 to 0.99 tonnes on the west coast (Fig. 2). Most of the variation in the total catch for each year was explained by a linear log-normal relationship between total catch and number of hooks (Fig. 3). The residual in this relationship is likely to be due to a combination of error in the estimates of total catch and variation in catch rates (see above) that is the result of variation in the availability of fish (e.g. due to movement and recruitment).

The size of Coryphaena taken by Japanese fleets is generally between 60 and $140 \mathrm{~cm}$ (fork length); (Fig. 4). The proportional representation of fishes of the different size classes varied among years. In 1992, for example, $39 \%$ of fish were $70-100 \mathrm{~cm}$ while in 1994 only 19\% were in this size range. Some caution should be taken with these comparisons where there is great variation in sample sizes.

Domestic fleets in Australia caught a total of $23,102 \mathrm{~kg}$ of Coryphaena on the east coast and 3,930 on the west coast (Table 2, data are only available for 1996.). The largest domestic fleet is on the east coast of Australia. Catches were made from 10$40^{\circ} \mathrm{S}$. Although numbers of hooks were greatest at southern latitudes, the lowest catch rates and total weight of Coryphaena were obtained at these latitudes (Table 2). This is primarily because the fishery targets tuna, not dolphinfish. This pattern should, however, be treated with caution until data are available for more years.

Coryphaena are rarely targeted around FADs in the commercial fishery. There have, however, been some initiatives in this area. For example, a series of FADs were deployed on the continental shelf break off south Western Australia (between Albany and Esperance) in the early nineteen eighties. Tuna pole and line vessels targeting juvenile southern bluefin tuna occasionally took Coryphaena by troll-line and pole and line around the FADs near Albany $\sim 35^{\circ} \mathrm{S}$, $118^{\circ} \mathrm{E}$. These FADs were not maintained after the mid-eighties. Although there is no network of FADs in Australia specifically designed to attract pelagic fishes and increase catches (c.f. Bombace, 1989; Higashi, 1994), this has been suggested as something that should be done for pelagic fisheries (Gorman, 1995).

Recreational fishing for Coryphaena exceeds the commercial catch in some areas of Australia (Steffe et al., 1996). Good data are only available for 'trail-

TABLE 2. - Catches of Coryphaena by the domestic longline fleet on the west and east coast of Australia. Catches are pooled by 5 degree latitude boxes and values for latitude refer to the northern end of the range. Number of hooks per fish gives some indication of effort.

\begin{tabular}{lcrrrr}
\hline Coast & Latitude & kg of Coryphaena & Number of Coryphaena & Number of hooks & Hooks per fish \\
\hline East & 10 & 841 & 108 & 242,000 & 2,241 \\
East & 15 & 9,802 & 1,234 & 593,392 & 481 \\
East & 25 & 8,858 & 680 & 574,723 & 845 \\
East & 30 & 3,314 & 410 & 763,198 & 2,462 \\
East & 35 & 287 & 451 & $1,087,673$ & 24,720 \\
West & all & 3,930 & & 434,010 & 962 \\
\hline
\end{tabular}



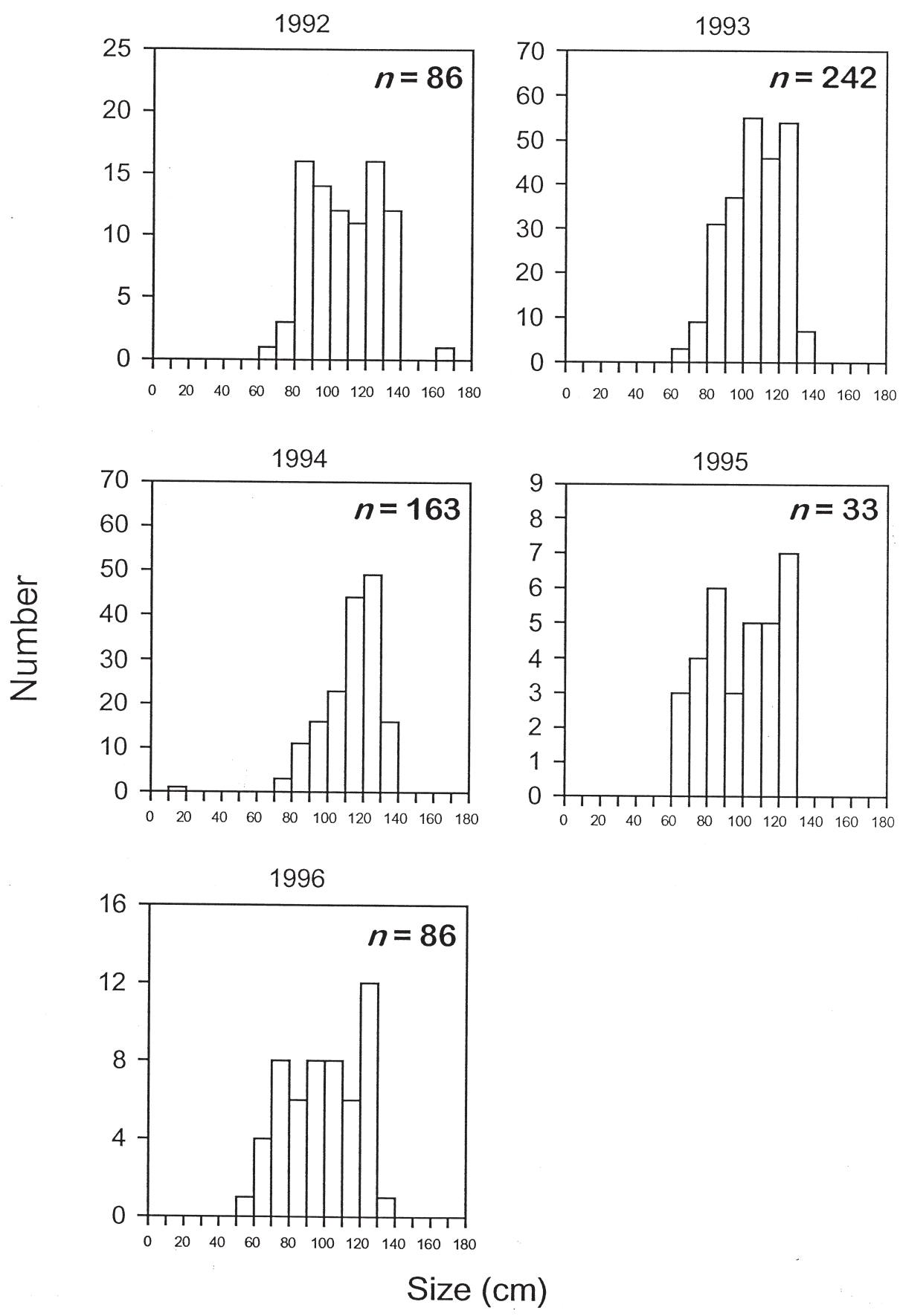

FIG. 4 - The size frequency of fish (fork lengths in cm) measured by observers on Japanese long-liners from 1992-1996. Note the scale of the $y$-axis varies for some of these plots.

er boat anglers' in New South Wales. The Steffe et al., (1996) survey was only done from major ports and estimated catches of 11.7 and 12.7 tonnes of Coryphaena in 1994 (September 1993-August 1994) and 1995 (September 1994-August 1995). These tonnages represented 1.1-1.8x that of the recorded commercial catch. Given that Coryphaena would have also been caught from ports that were not monitored and from charter boats, these esti- mates of recreational fishing are restricted to one state, and large quantities of fish are almost certainly caught in Queensland, Northern Territories and Western Australia. Recreational fishermen often capture Coryphaena around drifting or tethered objects. These accounts are largely anecdotal, however, and the objects the fish are captured around are not generally designed as FADs, but are navigation buoys and other devices. 
TABLE 3. - Records of monthly catches of Coryphaena off the north-eastern coast of New Zealand, for 1994-1996, when data on catches were considered reliable (Source: New Zealand Ministry of Fisheries, Licensed Fish Receiver Returns database, unpubl. data.).

Month January February March April May September December

\begin{tabular}{rrrrrrrr}
\hline 1994 & 296 & 1,149 & 219 & & & 262 & 107 \\
1995 & 30 & 186 & 13 & 605 & 10 & & \\
1996 & & 299 & 85 & & & & 12 \\
\hline
\end{tabular}

\section{Fishery in New Zealand}

Coryphaena have been caught by international and domestic fleets off the coast of New Zealand, but are considered a rare part of the by-catch (M. Francis pers. comm., NIWA Wellington, New Zealand). Foreign tuna long-line vessels, which ceased fishing about 2 years ago, did not report by-catch. Estimates of the catches by foreign vessels prior to 1993 are yet to be scaled for fleet size, but it is clear that very few dolphinfish were observed. The figures for the last 3-4 years are considered accurate for the fleet, and are the catch from the domestic fleet (1988 to 1991 , total of 2 to 14 kilograms per year; 1993, $5852 \mathrm{~kg} ; 1994,2033 \mathrm{~kg} ; 1995$, $844 \mathrm{~kg} ; 1996,404 \mathrm{~kg}$ ).

Most Coryphaena were caught in the Austral summer and early autumn when the warmest waters are found off the coast of north-eastern New Zealand (Table 3). A few fish were caught in September 1994, but it was rare for fish to be recorded in the Austral Spring and none were noted in winter.

\section{Incidental fisheries around New Guinea}

It is well known in the Pacific that Coryphaena associate with drifting (Heyerdahl, 1950) and tethered floating objects (e.g. Yabe and Mori, 1950; Higashi, 1994). Many of the Pacific nations in the South-west Pacific have deployed FADs for the purpose of attracting pelagic species (Boy et al., 1984), and in some cases to relieve fishing pressure from inshore resources (Kailola, 1995). Coryphaena are caught around these FADs, generally by trawling or handlining. Coryphaena are also incidental catches in the tuna purse-seine and pole-and-line fishery where they make up less than $1 \%$ of the catch around New Guinea (Kailola, 1995). The statistics on catches from New Guinea, and those from other Pacific Islands, are generally of variable quality.

\section{Tagging in Australia}

Of the $\sim 12,600$ fish tagged by recreational fishers, since the New South Wales game-fish tagging program began in 1973, there are only 119 recorded returns, and of these, 11 had no information on the release point. Furthermore, some records of the remaining 108 fish (e.g. length at time of recapture) are incomplete. This is a very low percentage return ( $0.86 \%$ recovery) compared to other programs for pelagic fish such as carangids of the genus Seriola spp. (3.5-16.4\%; in Gillanders et al., 1997). In our analyses, fish were only selected if they had been at large for 10 days or more and for which size at recapture was zero or more. This assumed that negative values were due to measurement error $n=17$.

Although calculations of distance moved are conservative when based on a tag and a recapture point, many fish were caught in the same position where they were tagged and even on the same day. It is common for fish to be recaptured in the same
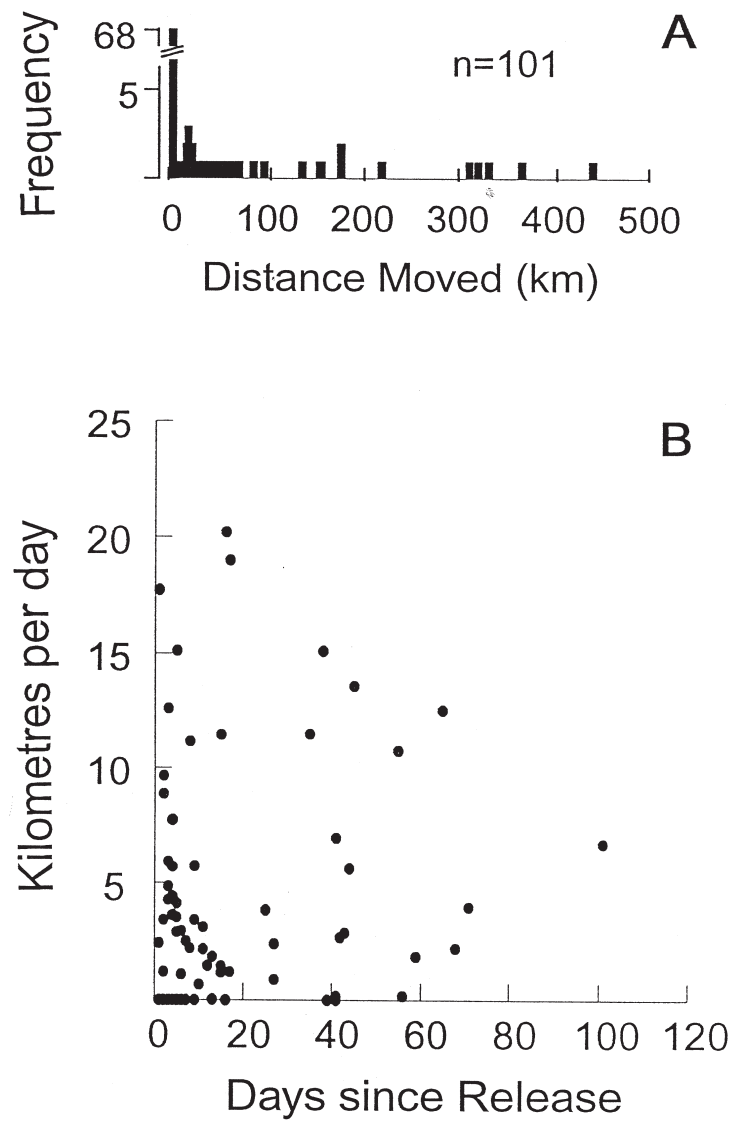

FIG. 5 - The movements of Coryphaena on the eastern coast of Australia, tag data of Fisheries of New South Wales, Australia; all data refer to fish that were released for 1-120 days. (A) total distance moved (i.e. distance from tag to recapture point); (B) distance covered per day; Correlation: $n=101, r=0.037$, Not significant at $\mathrm{p}=0.05$. 
position where they were tagged because they commonly associate with floating objects such as wave rider buoys, which are targeted by fishermen (Mathews and Deguara, 1994). In contrast, other Coryphaena travelled up to $20 \mathrm{~km}$ per day and up to 440 kilometres in 120 days or less (Fig. 5). Three fish were recaptured up to 360 days after tagging; two of them were recaptured in the same position where they were tagged and 1 had moved 120 kilometres $(<2 \mathrm{~km} /$ day $)$ in that time.

The direction of movement was determined by a crude comparison of the place of recapture with the place of release, only considering fishes that had moved $10 \mathrm{~km}$ or more. This selection resulted in a sample size of 30 . Although the sample size was low, there was a suggestion that fishes recaptured in the austral summer and early autumn tended to move south and north, while by late Autumn and winter most fish moved toward the north (Table 4). Data of this type are, however, of questionable quality given that the direction of movement of fish may be partly constrained by the latitude at which they were taken. For example, fishes tagged near the southern limit of the species are likely to only move north. Furthermore, the location and number of recaptures may vary with changes in fishing effort. Equal allocation of sampling effort is almost impossible with amateur programs.

Estimates of rates of growth were obtained from tagged fish, but the data were limited to 17 fish that had been at large for more than 10 days for which zero or positive growth rates were measured (Fig. 6). There was a positive relationship between length of Coryphaena and rate of growth. Only $24 \%$ of the variation in the data was explained by the relationship. This is likely to be due to seasonal difference in rates of growth (which are not factored into this model) and measurement error, which can be great if fish are not measured carefully. We found that $43 \%$ of fish were recorded as having negative growth and were excluded from analyses. It is also common for

TABLE 4. - The direction of movement of tagged Coryphaena off the coast of New South Wales, Australia. Fish were selected for this comparison if they had moved more than $10 \mathrm{~km}$ from the time of tagging and had been at large for 1-120 days; $n=30$ fish. All of the fish were released within a latitudinal range of $29-37^{\circ} \mathrm{S}$ (i.e. within New South Wales).

\begin{tabular}{lcccc}
\hline TimelDirection & North & South & West & East \\
\hline January-March & 4 & 7 & 0 & 0 \\
April-August & 12 & 3 & 1 & 2 \\
\hline
\end{tabular}

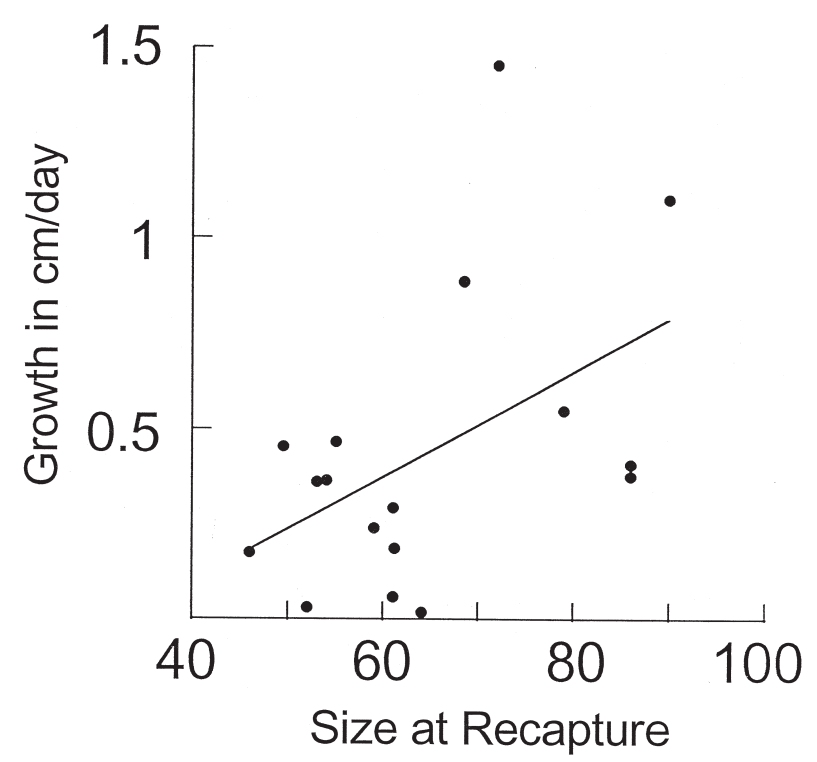

FIG. 6 - Growth of tagged Coryphaena off the east coast of Australia. Formula of the regression line: Growth per day $=0.014 *$ Fork Length- 0.455 .

amateurs to round measurement to the nearest 5 or $10 \mathrm{~cm}$ (Gillanders et al., 1997). From the data presented in Figure 6, we would only argue that larger fish appeared to grow at a faster rate than small fish, perhaps because the largest fish were less than 90 $\mathrm{cm}$ whereas the largest fish in the fishery were $>130$ $\mathrm{cm}$ (FL). Growth rates of 0.1 to $0.6 \mathrm{~cm} /$ day have been recorded for other Coryphaena (Oxenford and Hunte, 1983) and rates of up to $1 \mathrm{~cm}$ per day have been recorded in sea farms ( $\mathrm{H}$. Oxenford, pers. comm.). It is likely, therefore, that estimates of growth in excess of $0.6 \mathrm{~cm} /$ day are due to reader error ( $\mathrm{n}=3$ fish).

\section{Larval forms}

Coryphaena larvae have been caught along the east coast of Australia in Queensland and at the southern end of the East Australia Current (EAC) in New South Wales (Fig. 1). A. Miskiewicz has collected larvae Coryphaena along the coast of New South Wales. Data are available for three sampling designs: (1) approximate monthly sampling at the entrance to Lake Macquarie (Swansea Channel, $\left.33^{\circ} \mathrm{S}\right)$ over a period of three years (1981-1983; see Miskiewicz, 1986, with $500 \mu \mathrm{m}$ mesh net $\left(0.5 \mathrm{~m}^{2}\right.$ mouth); (2) three cruises along the coast of New South Wales $\left(28^{\circ} \mathrm{S}\right.$ to $\left.34^{\circ} \mathrm{S}\right)$ during the Austral Summer and Autumn in January, March and May of 1983 and a single cruise in 1989 (see Miskiewicz et al., 1996); where oblique and surface hauls with a 
$500 \mu \mathrm{m}$ mesh net were used $\left(0.39 \mathrm{~m}^{2}\right.$ mouth $)$ and; (3) sampling off the coast of Sydney $\left(34^{\circ} \mathrm{S}\right)$ approximately every six weeks for 12 months in 1990 and in waters of 60-100 m depth. Depth stratified tows were done at the surface and $30 \mathrm{~m}$ with a $500 \mu \mathrm{m}$ mesh net $\left(0.39 \mathrm{~m}^{2}\right.$ mouth $)$; sampling design and map see Gray $(1993,1996)$.

The larvae captured in sampling designs 1-3 ranged from preflexion forms under $5 \mathrm{~mm}$ notochord length to $20 \mathrm{~mm}$ (see larval descriptions in Moser, 1996), and most larvae were collected during the Austral summer and autumn when the EAC reaches its seasonal southern limit. In sampling design 1, seven larvae were caught between December 1992 and April 1993. A total of 24 larvae were collected along the coast of New South Wales in the 1983 cruises of design 2 and 20 of these were caught in surface waters. A total of 14 larvae were collected in 1989. It was also noted by Miskiewicz (pers. comm.) that most fish were caught in warm waters of the EAC. A total of 5 larvae were caught in design 3 . With the exception of one larva captured in November, all other larvae were collected in MarchApril. These data indicate, therefore, that some adult Coryphaena spawn in New South Wales, but many of the larvae are probably advected south from spawnings in Queensland.

Incidental catches of Coryphaena larvae on the east coast Australia have included: Leis and Goldman (1987; present at Carter Reef 1440'S) and Kingsford and Suthers (1996; with drift algae, $\mathrm{n}=1,34^{\circ} \mathrm{S}$, Botany Bay). As for the observations of Miskiewicz above, Young et al., (1986) caught low concentrations of Coryphaena in 'oceanic' and 'slope' tropical waters off the north-west shelf Australia (approximate position of the study area, $19^{\circ} \mathrm{S}, 118^{\circ} \mathrm{E}$ ) and Leis (1993) found that Coryphaena larvae represented 0.6$1.5 \%$ of larvae in 'offshore samples' near Lizard Island, Great Barrier Reef (14³3’S').

\section{Aquaculture}

Trials for the raising of Coryphaena were done at Bribie Island Aquaculture Centre (near Brisbane), but were discontinued due to problems with water quality (Anon., 1995). In contrast, Coryphaena have been raised successfully in Western Australia by Mariculture Development Pty Ltd (Contact Steve Nel, 44 Brazier Rd, Yanchep 6035, Western Australia). The company has a land-based farm that is capable of producing 200 tonnes of fish a year. The initiative is likely to go commercial in 1999.
The qualities that make Coryphaena ideal for commercial farming are: high fecundity and continuous spawning; exceptional growth rate, efficient food conversion and a high market price (greater than $\$ 10$ Aus. per $\mathrm{kg}$ ). All of these qualities are superior to most other marine fish used in aquaculture (Nel, 1995, 1996). Nel (1995) noted that adult fish can spawn naturally once every 48 hours, throughout the year, without the need for hormonal injections. Moreover, each female can produce over 250,000 eggs on each spawning occasion. Continuous spawning meant that the brood stock hatchery and nursery facilities could be comparatively small. Nel found that Coryphaena grew from eggs to 2.5 $\mathrm{kg}$ in 6 months and more than $10 \mathrm{~kg}$ in 12 months. The food conversion ratio (FCR) was 1.2:1, indicating that increases in the supply of food directly translate into profitability. Nel concluded that a well designed and managed farm could supply fresh fish throughout the year and respond quickly to changes in market conditions.

\section{ACKNOWLEDGEMENTS}

This review required information from many sources and we thank the following: Malcolm Francis for making us aware of data on catches in New Zealand waters and John Annala for allowing us to use the data from the LFRR database; Andrew Richards and Johanne Bell of FAA in the Solomons for providing us with cryptic reports on pelagic fishes from the Pacific Islands; Bronwyn Gillanders for making us aware of data on tagging and Karen Thompson, of New South Wales Fisheries, for providing data on the tagged fishes; Tony Miskiewicz for unpublished data on the distribution of larvae in Australian water; and Steve Nel for providing information on the commercialisation of Mahi mahi. The data on catches of dolphinfish were extracted from the database of the AFZ Observer Program, Australian Fisheries Management Authority (AFMA) in Canberra. We also thank Bronwyn Gillanders and Michael Finn for constructive criticism of the manuscript, and gracias a Teque Rodriguez who helped with the translation of the summary.

\section{REFERENCES}

Anon. - 1995. Potential for commercial marine fish farming for NSW. Prepared by the Pacific seafood Management Consulting Group Pty Ltd, for the NSW OLMA Aquaculture, Fishing and 
related Industries Committee Inc. (NOFARIC) pp. 6-7

Ayling, A.M. and G.J. Cox. - 1982. Collins guide to the sea fishes of New Zealand. Collins Auckland, pp. 343.

Bombace, G. - 1989. Artificial reefs in the Mediterranean Sea. Bull. Mar. Sci., 44: 1023-1032.

Boy, R.L. and B.R. Smith.. - 1984. Design improvements to fish attraction device (FAD) mooring systems in general use in Pacific Countries. SPC Handbook 24. South Pacific Commission, Noumea, New Caledonia $77 \mathrm{pp}$.

Baron, M. - 1991. Longlining: what does it involve? Australian Fisheries, May: 18-23.

Clarke, K.R. - 1993. Non-parametric multivariate analyses of changes in community structure. Aust. J. Ecol., 18: 117-143.

FAO. - 1984. Volume II. In: Fischer, W. and G., Bianchi (eds.), FAO Species Identification sheets for fishery purposes: Western Indian Ocean, Fishing Area 51, pp. Coryphaenidae 1-6. FAO, Rome.

Gillanders, B.M., D.J. Ferrell and N.L. Andrew. - 1997. Determination of aging in kingsfish (Seriola lalandi in New South Wales Waters. Fisheries Research and Development Corporation, Project No. 95/128, ISBN 0731094069103 pp.

Gomon, M.F., J.C.M. Glover and R.H. Kuiter. - 1994. The fishes of Australia's South Coast. State Print Adelaide, 992 pp.

Gray, C.A. - 1993. Horizontal and vertical trends in the distributions of larval fishes in coastal waters off New South Wales, Australia. Mar. Biol. 116: 649-666.

Gray, C.A. - 1996. Small-scale temporal variability in assemblages of larval fishes: implications for sampling. J. Plank. Res., 18: 1643-1657.

Heyerdahl, T. - 1950. The Kon-Tiki Expedition: by raft across the south seas. George Allen \& Unwin Ltd London, $235 \mathrm{pp}$.

Higashi, G.R. - 1994. Ten years of fish aggregation device (FAD) design development in Hawaii. Bull. Mar. Sci., 55: 651-666.

Holbrook, S.J., M.J. Kingsford, R.J. Schmitt and J.J.S. Stephens. 1994. Spatial patterns of marine reef fish assemblages. Am. Zool., 34: 463-475.

Hunter, J. and C.T. Mitchell. - 1967. Association of fishes with flotsam in the offshore water of Central America. Fish. Bull. U.S., 66: $13-29$.

Kailola, P.J. - 1995. Fisheries Resources Profiles: Papua New Guinea. Forum Fisheries Agency Report No. 95/45, 95pp

Kailola, P.J., M.J. Williams, P.C. Stewart, R.E. Reichelt, A. McNee and C. Grieve. - 1993. Australian Fisheries Resources. Bureau of Resource Sciences and the Fisheries Research and Development Corporation Canberra, $422 \mathrm{pp}$.

Kingsford, M.J. and J.H. Choat. - 1985. The fauna associated with drift algae captured with a plankton-mesh purse-seine net. Limnol. Oceanogr., 30: 618-630.

Kingsford, M.J. and I.M. Suthers. - 1996. The influence of phase of the tide on patterns of ichthyoplankton abundance in the vicinity of an estuarine front, Botany Bay, Australia. Est. Coast. Shelf Sci., 43: 33-54.

Kuwahara, A., K. Washio and S. Suzuki. - 1982. Relationship between fishing conditions of sailfish and dolphinfish and fluctuation of hydrographic condition in the sea off Kyoto Prefecture. Bull. Jap. Soc. Fish. Oceanogr., 40: 3-8.
Leis, J.M. - 1993. Larval fish assemblages near Indo-Pacific Coral Reefs. Bull. Mar. Sci., 53: 362-392.

Leis, J.M. and B. Goldman. - 1987. Composition and distribution of larval fish assemblages in the Great Barrier Reef Lagoon, near Lizard Island, Australia. Aust. J. Mar. Freshw. Res., 38: 211-223.

Mathews, J. and K. Deguara. - 1994. Gamefish Tagging Newsletter 1993-94. Fisheries Research Institute of New South Wales, $16 \mathrm{pp}$.

Miskiewicz, A.G. - 1986. The season and length at entry into a temperate Australian estuary of the larvae of Acanthopagrus auatralis, Rhabdosargus sarba and Chrysophyrs auratus (Teleostei: Sparidae). In: Uyeno, T., R., Arai, T., Taniuchi and K., Matsuura (eds.), Indo-Pacific Biology: Proceedings of the 2nd International Conference on Indo-Pacific Fishes, pp. 740747. Ichthyological Society of Japan, Tokyo.

Miskiewicz, A.G. B.D. Bruce and P. Dixon - 1996. Distribution of Tailor (Pomatomus saltatrix) Larvae along the coast of New South Wales, Australia. Marine and Freshwater Research, 47: 331-336.

Moser, H.G. - 1996. The early stages of fishes in the California Current region. Allen Press, Inc. Kansas, 1505 pp.

Nel, S. - 1995. Commercialisation of mahi mahi. Australasia Aquaculture, 9(6): 51-53.

Nel, S. - 1996. Investing in Aquaculture-an emerging aquabusiness. Outlook 1996, Commodity Markets \& Resource Management, Volume 1. Proceedings of the National Agricultural and Resources Outlook Conference, Canberra, 6-8 February 1996, pp. $221-230$

Norton, J. and S.J. Crooke. - 1994. Occasional availability of dolphin, Coryphaena hippurus, to southern California commercial passenger fishing vessel anglers: observations and hypotheses. CalCOFI Rep., 35: 230-239.

Oxenford, H.A. and W. Hunte. - 1983. Age and growth of dolphin, Coryphaena hippurus, as determined by growth rings in otoliths. Fish. Bull., 84: 906-909.

Oxenford, H.E. - 1986. A preliminary investigation of stock structure of the dolphin, Coryphaena hippurus, in the Western Central Atlantic. Fish. Bull. U.S., 84: 451-459.

Steffe, A.S., J.J. Murphy, D.J. Chapman, G.N.G. Tarlinton, G.N.G. Gordon and A. Grinberg. - 1996. An assessment of the impact of offshore recreational fishing in New South Wales waters on the management of commercial fisheries. Final Report to the Fisheries Research and Devlopment Corporation, Project No. 94/053, ISBN 0731094050,140 pp.

Ward, P.J. - 1996. Japanese long-lining in eastern Australia 19621990. Bureau of Resource Sciences Canberra, 247 pp.

Yabe, H. and T. Mori. - 1950. An observation on the habit of bonito, Katsuwonus vagans, and yellow fin, Neothunnus macropterus, school under the drifting timber on the surface of ocean. Bull. Jpn. Soc. Sci. Fish., 16: 35-39.

Young, P.C., J.M. Leis and H.F. Hausfeld. - 1986. Seasonal and spatial distribution of fish larvae in waters over the North West continental shelf of western Australia. Mar. Ecol. Prog. Ser., 31: $209-222$. 